Members of the European Parliament have also expressed their displeasure, last week voting by a narrow majority to defer approval of EFSA's 2010 budget report. The sanction is largely symbolic and of little practical consequence, but it is another blow to the authority's reputation.

As part of the same vote, the parliament also sanctioned the European Medicines Agency and the European Environment Agency over similar issues. Jacqueline McGlade, the director of the European Environment Agency, based in Copenhagen, has been chastised for concurrently serving on the board of the Earthwatch Institute, an international environmental research and advocacy non-profit body, which has received funding from the agency. And in March, the European Medicines Agency in London was forced to place restrictions on former executive director Thomas Lönngren's employment for the next two years, following questions about his work as a pharmaceutical industry consultant.

Geslain-Lanéelle says she hopes that parliament will lift its sanction when it votes on the matter again in the autumn, after it has received a report from the European Court of Auditors on the handling of potential conflicts of interest at EFSA.

But Bánáti warns that the authority's conflict-of-interest rules risk becoming too restrictive. "It is important to understand that scientists who work for EFSA do so in an unpaid capacity, offering their expertise as a public service," she says. "EFSA should respect the free choices of all the scientists of which it has need to do its valuable work, to manage their own careers and make their own choices as they see fit." - SEE EDITORIAL P.279

\title{
Go West, young Russian
}

\section{President Putin to back scheme for students to study abroad.}

\section{BY QUIRIN SCHIERMEIER}

$\mathrm{I}$ $\mathrm{n}$ an effort to grow its scientific workforce and to stimulate international research collaborations, the Russian government is set to pay for thousands of Russian students to attend top universities around the world. But to benefit from the generous scholarships, the students must agree to apply their new-found skills back home - assuming that jobs will be waiting for them when they return.

Vladimir Putin, who took office as president last week following a controversial election, is expected to officially approve the five-billionrouble (US\$165-million) Global Education programme by the end of this month. His pre-election promises included a pledge to substantially increase government funding of science and education (see Nature 483, 253-254; 2012).

The programme will be run by the Strategic Initiatives Agency, a government-funded bureau set up last year with a view to promote social and economic innovation in Russia. The first call for applications should be launched next month, says Dmitry Peskov, who is head of the agency's division for young professionals and oversees the programme. "We have the means to very generously support up to 2,000 talented Russian students per year," he says.

The scheme will initially operate for three years, but may be extended following a performance review planned for 2015. Students in all fields of science, technology, medicine, social science and business will be eligible for the grant - as long as they attend one of the top 300 universities in the Times Higher Education World University Rankings, says Peskov.

$\rightarrow$ NATURE.COM For more on Russian science, see: go.nature.com/bcgxcs

\section{AFTER THE FALL}

Russia's ministry of education and science estimates that the country now has only onequarter of the number of researchers who were working during the prime of the Soviet Union.

$$
1.5
$$

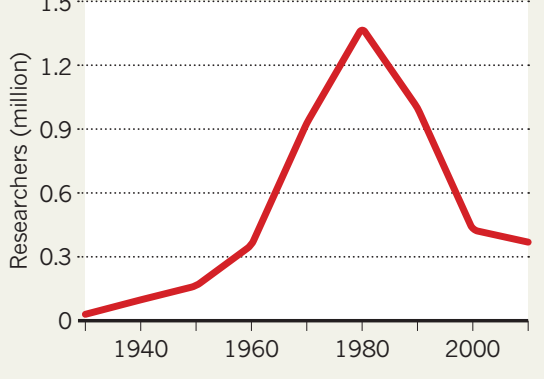

to sign a contract with the agency, in which they agree to return to Russia and secure professional work there for at least three years after graduation. If they sign up, the agency will cover their travel, tuition fees and living expenses. But they will also be obliged to pay back the full stipend if they choose not to return.

"The good thing is that the initiative is in the hands of students, who will be selected - or not - on the basis of merit by foreign schools," says Konstantin Severinov, a molecular biologist at Rutgers University in Piscataway, New Jersey, who runs research groups at the Russian Academy of Sciences' institutes for molecular genetics and gene biology in Moscow. "That way, Russian university administrators cannot exert too much control" over which students receive the awards, he says.

Although he welcomes the scheme, Severinov warns that it is far from certain that there will be adequate career opportunities for the returnees. Russian science continues to struggle to regain the strength of its Soviet glory days (see 'After the fall'), and domestic hightechnology industries are still in their infancy. In the short term, the lack of jobs may force these students to seek work abroad, says Severinov, contributing to the brain drain that the programme is meant to reduce.

However, similar schemes have proven effective in other countries. China - now a scientific powerhouse - has benefited considerably from government-sponsored overseas training of hundreds of thousands of students since the 1970s. The students' international experience also helps to bolster international research partnerships once they return home. A smaller programme, running since 1994, has helped to rejuvenate science in Kazakhstan. And Brazil, where scientists and engineers are in high demand, last year announced plans to send 75,000 students abroad by the end of 2014 (see Nature go.nature.com/x4vaoy; 2011).

Working with foreign supervisors can help to open up valuable research opportunities, says chemist Xinjiao Wang of the Ruhr University Bochum, Germany. Last year, the China Scholarship Council, based in Beijing, which funds international study, gave Wang an 'outstanding student' award worth $\$ 5,000$ for her graduate research on nickel compounds at the University of Erlangen-Nürnberg, Germany. "In Germany, I've really learned how to create new ideas in science," she says.

\section{CORRECTION}

In the Editorial 'Price of freedom' (Nature 485, 148; 2012), we stated that 'plenty of European scientists will be lost'. 'European scientists' should have been 'Europan science', as we meant to refer to science on the Jovian moon Europa. 